\title{
GMR
}

\section{Polymorphisms and alternative splicing of the luteinizing hormone receptor of dairy cattle}

\author{
S. Wohlres-Viana ${ }^{1}$, E.K.N. Arashiro ${ }^{3}$, D.R.L. Reis ${ }^{2}$, L.E. Fernandes ${ }^{2}$, \\ M.G.C.D. Peixoto ${ }^{2}$, M.A. Machado ${ }^{1,2}$ and J.H.M. Viana ${ }^{3}$ \\ ${ }^{1}$ Instituto de Ciências Biológicas, Universidade Federal de Juiz de Fora, \\ Juiz de Fora, MG, Brasil \\ ${ }^{2}$ Laboratório de Genética Molecular, Embrapa, Juiz de Fora, MG, Brasil \\ ${ }^{3}$ Laboratório de Reprodução Animal, Embrapa, Juiz de Fora, MG, Brasil \\ Corresponding author: J.H.M. Viana \\ Email: henrique.viana@embrapa.br \\ Genet. Mol. Res. 15 (2): gmr.15027046 \\ Received June 18, 2015 \\ Accepted November 5, 2015 \\ Published June 3, 2016 \\ DOI http://dx.doi.org/10.4238/gmr.15027046
}

\begin{abstract}
The aim of this study was to screen for variability in the luteinizing hormone/choriogonadotropin receptor (LHCGR) and to determine the occurrence of LHCGR mRNA isoforms in two dairy breeds of cattle. Granulosa cells from dominant ovarian follicles were recovered from 16 Gir and 16 Holstein cows, and total RNA was extracted. Complementary DNA was synthesized and PCR was used to generate amplicons for sequencing. Chromatograms were evaluated, and multiple sequences were aligned and analyzed for the presence of polymorphisms, allele frequency, polymorphic information content (PIC), and Hardy-Weinberg equilibrium (HWE). Twentyone single nucleotide polymorphisms (SNPs) were identified in $\mathrm{LH}$ receptor mRNA. Seventeen SNPs were identified in Gir cattle (seven exclusively), and 14 were found in Holstein cattle (four exclusively). Seven of the 21 polymorphisms found did not alter which amino acid was translated. Eight SNPs caused a change to an amino acid in a different chemical group. Classification of SNPs according to PIC values identified 12 as being highly informative in Gir cattle and five in
\end{abstract}


Holstein. Eight SNPs deviated from HWE in Gir compared with 11 in Holstein, and eight in both breeds. Two isoforms were also identified, one in exon 1, which lacks 30 nucleotides beginning at position 118, and the other in exon 10. Taken together, these data show that LHCGR in dairy cattle breeds has a high frequency of polymorphism and exists in multiple isoforms resulting from alternative splicing.

Key words: $L H C G R$ isoforms; Reproduction; Zebu

\section{INTRODUCTION}

The dynamics of follicular development in several species, including bovine, are characterized by successive waves of growth during the estrous cycle (Adams et al., 2008). In each growth wave, a set of follicles develops simultaneously, and subsequently, one follicle is selected as dominant. The dominant follicle blocks the development of the remaining follicles by suppressing the concentrations of follicle stimulating hormone (FSH), which is released by the pituitary gland (Ginther et al., 2001a). In this environment, the dominant follicle must undergo changes that enable it to continue developing at lower concentrations of FSH. The major change involves transitioning from a primary dependency on FSH to luteinizing hormone (LH) (Ginther et al., 2001b), which is mediated by the increased expression of the luteinizing hormone/choriogonadotropin receptor gene (LHCGR) in granulosa and theca cells at the time of dominant follicle selection. Ovulation is triggered by LH binding to its receptor on the membrane of granulosa and theca cells in mature ovarian follicles. This activates several signal transduction pathways, which induce inflammatory processes and alter gene expression, resulting in modification of follicular morphology, culminating in rupture (Espey and Lipner, 2006).

The expression of LHCGR in follicular granulosa cells is required for the establishment of a species-specific ovulation rate (Ginther et al., 2001b) and ultimately for fertility. Polymorphisms and alternatively spliced isoforms of $L H C G R$ may also interfere with LH-regulated events. For example, several polymorphisms in LHCGR impair reproductive outcomes in humans (Themmen, 2005). In cattle, the presence of single nucleotide polymorphisms (SNPs) in this receptor is associated with variations in fertility and production traits (Hastings et al., 2006; Santos-Biase et al., 2012). However, these studies only examined exon 11 of $L H C G R$ and no information is available on the remaining 10 exons. Studies evaluating the structure of $L H C G R$ mRNA in several other species have shown that isoforms exist (Abdennebi et al., 2002; Kawate, 2004; Madhra et al., 2004; Nogueira et al., 2007). It has been hypothesized that some of these isoforms are non-functional, but the significance of their expression remains unclear.

The genomic and transcriptomic characterization of LHCGR in livestock may be useful for understanding differences in reproductive traits within breeds, such as those observed between Bos primigenius taurus and B. primigenius indicus. It will also be important to define the association of these variants with reproductive phenotypes, which may guide future animal selection. Moreover, it may also provide information about $L H C G R$ that contributes to human medicine. Dairy breeds of cattle provide an interesting model for the study of $L H C G R$ since, for decades, there has been a strong selective pressure on milk production, with a clear interference in reproductive performance and a reduction in breeding values for fertility (Royal et al., 2000; Washburn et al., 2002; Weigel, 2004; Butler, 2013). However, to our knowledge, the impact 
of selection for milk production traits has not been reported for indicine breeds, possibly owing to their recent and low selection pressure. In addition, $B$. primigenius taurus and $B$. primigenius indicus breeds are remarkably different in ovarian follicular dynamics and in their response to assisted reproductive technologies (Sartori et al., 2010). Therefore, in this study, $L H C G R$ variability in dairy cattle was screened using criteria of polymorphic information content (PIC), Hardy-Weinberg equilibrium, (HWE) and the occurrence of LHCGR isoforms.

\section{MATERIAL AND METHODS}

\section{Animal population and location}

This study was performed at the Animal Reproduction and Molecular Genetics Laboratories at Embrapa Gado de Leite, Juiz de Fora, Minas Gerais, Brazil. Granulosa cells (GC) and blood samples were collected from multiparous, non-pregnant and non-lactating cows from Gir (B. primigenius indicus, $\mathrm{N}=16$ ) and Holstein (B. primigenius taurus, $\mathrm{N}=16$ ) breeds. The cows were from herds with mixed lineages and specifically selected to avoid at least two generations of direct relationships among sires or dams. All procedures performed using research animals were conducted in accordance with the Brazilian Ethics, Bioethics, and Animal Care Committee (CEBEA) guidelines and were approved by the Embrapa Ethics in the Use of Animals Committee (Protocol CEUA-CNPGL 03/2013).

\section{Sample recovery and processing}

Our group previously showed that the diameter of the dominant follicle at deviation was larger in Holstein than in Gir cattle $(8.7 \pm 0.1 \mathrm{~mm} v s 6.9 \pm 0.5 \mathrm{~mm}$, respectively) (Arashiro et al., 2013a). Therefore, we used GCs recovered from dominant follicles (after deviation) at $10 \mathrm{~mm}$ for Holstein, and $8 \mathrm{~mm}$ for Gir. GC samples were obtained as previously described (Arashiro et al., 2013b) and kept at $-20^{\circ} \mathrm{C}$ until RNA extraction. Total RNA was extracted using the RNeasy Micro Kit (Qiagen GmbH, Hilden, Germany) according to the manufacturer instructions. Samples were quantified using a NanoDrop spectrophotometer (Thermo Scientific, Waltham, MA, USA), and quality was assessed using an Agilent Bioanalyzer 2100 (Agilent, Palo Alto, CA, USA). Reverse transcription was performed using the SuperScript III First-Strand Synthesis SuperMix kit (Invitrogen, Carlsbad, CA, USA) according to the manufacturer instructions. The samples were kept at $-80^{\circ} \mathrm{C}$ until PCR analysis.

For genomic DNA extraction, blood samples from Gir and Holstein cows were collected using vacuum tubes containing EDTA. Leukocytes were separated from fresh whole blood and transferred to 2-mL tubes. Samples were washed with lysis buffer until a white pellet was obtained. The pellet was then treated with saline-proteinase $\mathrm{K}$ buffer and protein was removed by phenol-chloroform treatment. DNA was precipitated with isopropanol/ sodium acetate. The pellet was rehydrated with $70 \%$ ethanol, resuspended in Tris-EDTA, and quantified by spectrophotometry.

\section{PCR and sample purification}

Primers were designed using the Primer3 tool (http://frodo.wi.mit.edu/primer3), according to the $B$. primigenius taurus luteinizing hormone receptor sequence available in 
GenBank (www.ncbi.nlm.nih.gov; accession No. NM_174381.1) or the literature referenced (Table 1). Primers were designed to generate amplicons that overlap in approximately 70 base pairs (Figure 1).

Table 1. Primer names and sequences, fragment sizes, annealing temperatures (AT), primer concentration $(\mathrm{nM})$ and references.

\begin{tabular}{|c|c|c|c|c|c|}
\hline Primer & Sequence (5'-3') & Size (bp) & AT $\left({ }^{\circ} \mathrm{C}\right)$ & Concentration (nM) & Reference \\
\hline \multirow[t]{2}{*}{ LHR1 } & F: ATGGGACGGCCGTCCCTCGCGCTGAGG & \multirow[t]{2}{*}{666} & \multirow[t]{2}{*}{65} & \multirow[t]{2}{*}{300} & \multirow{2}{*}{ Kawate, 2004} \\
\hline & R: CCCCCGGAAGGCGTCGTTGTGCATCTTCT & & & & \\
\hline \multirow[t]{2}{*}{ LHR2 } & F: GCCTCAGCCGACTATCACTC & \multirow[t]{2}{*}{223} & \multirow[t]{2}{*}{50} & \multirow[t]{2}{*}{300} & - \\
\hline & R: CCGAGGGAGATTTGTAAACG & & & & - \\
\hline \multirow[t]{2}{*}{ LHR3 } & F: ATGCCTTTGACAACCTCCTC & \multirow[t]{2}{*}{462} & \multirow[t]{2}{*}{52} & \multirow[t]{2}{*}{200} & - \\
\hline & R: GAATGGACTCTAGCCCGTAGG & & & & - \\
\hline \multirow[t]{2}{*}{ LHR4 } & F: CTGGAGCTGAAGGAAAATGC & \multirow[t]{2}{*}{387} & \multirow[t]{2}{*}{50} & \multirow[t]{2}{*}{300} & - \\
\hline & R: ATCCCAGCCACTCAGTTCAC & & & & Robert et al., 2003 \\
\hline \multirow[t]{2}{*}{ LHR5 } & F: GAAAGCACAGCAAGGAGACC & \multirow[t]{2}{*}{281} & \multirow[t]{2}{*}{53} & \multirow[t]{2}{*}{300} & - \\
\hline & R: GTCTGCAAAGGCGAGGTTGC & & & & - \\
\hline \multirow[t]{2}{*}{ LHR6 } & F: CAAACTGACAGTCCCCCGCTTT & \multirow[t]{2}{*}{335} & \multirow[t]{2}{*}{52} & \multirow[t]{2}{*}{300} & Marson et al., 2008 \\
\hline & R: GCAACACGGCAATGAGAGTA & & & & Hastings et al., 2006 \\
\hline \multirow[t]{2}{*}{ LHR7 } & F: CAAAAGCTGCGACTGAAACA & \multirow[t]{2}{*}{484} & \multirow[t]{2}{*}{48} & \multirow[t]{2}{*}{500} & - \\
\hline & R: CAACAGAAAGAAATCCCTTTGG & & & & Robert et al., 2003 \\
\hline \multirow[t]{2}{*}{ LHR8 } & F: ATCCAGAGCTGATGGCTACC & \multirow[t]{2}{*}{425} & \multirow[t]{2}{*}{50} & \multirow[t]{2}{*}{300} & - \\
\hline & R: ATAGCAAGTCTTGTCCAGGA & & & & Nogueira et al., 2007 \\
\hline \multirow[t]{2}{*}{ LHR9 } & F: AAAGGCATTCCAAAGGGATT & \multirow[t]{2}{*}{462} & \multirow[t]{2}{*}{47} & 500 & - \\
\hline & R: - TACTACCCAAAGCAATTTATAGATTC & & & & - \\
\hline LHR DNA & FORWARD LHR1 & 172 & 60 & 300 & Kawate, 2004 \\
\hline & R: CTCACAGTCGGCTGAGGCCG & & & & - \\
\hline
\end{tabular}

AT: annealing temperature. N/A: no reference required. Primer sequence designed for this study.

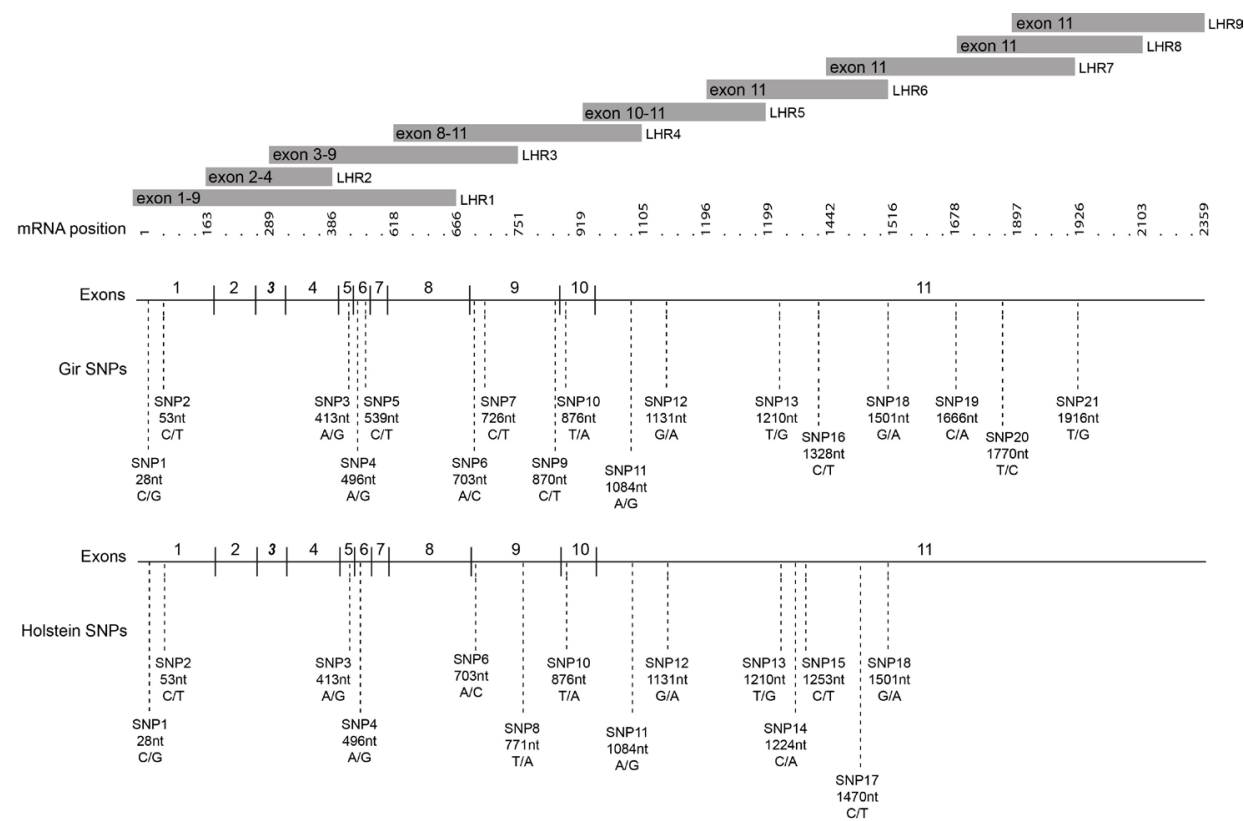

Figure 1. Schematic representation of the structure of $L H C G R$ mRNA in dairy cattle. Boxes show the primers coverage and its overlap through the sequence. The numbered line (dotted) shows the mRNA position in nucleotides (nt). The exons line (solid) shows each exon position and the SNPs identified in each breed. 


\section{PCR protocol 1:}

Each PCR reaction mix contained PCR buffer (1X), $\mathrm{MgCl}_{2}(2 \mathrm{mM})$, dNTPs $(0.2$ $\mathrm{mM}$ ), Primers (forward and reverse, Table 1), Hot Start Taq Polymerase (1 U, Promega, Madison, WI, USA), cDNA (equivalent to $8 \mathrm{ng}$ RNA), and water up to a $20-\mu \mathrm{L}$ final volume. The LHR1 primer had a GC content of approximately $70 \%$; therefore, $2 \mathrm{M}$ Betaine (Sigma-Aldrich, Saint Louis, MO, USA) was used to improve amplification. For this primer, the PCR protocol was $94^{\circ} \mathrm{C}$ for 2 min followed by 40 cycles of $94^{\circ} \mathrm{C}$ for $45 \mathrm{~s}$, $65^{\circ} \mathrm{C}$ for $30 \mathrm{~s}$, and $72^{\circ} \mathrm{C}$ for $1 \mathrm{~min}$.

\section{PCR protocol 2:}

In order to amplify a fragment of the initial region of the transcript that was smaller than that amplified with the primer set for LHR1, we performed another round of amplification using the LHR1 forward and LHR2 reverse primers. The PCR was performed as described for Protocol 1. Owing to the difference in the $\mathrm{GC}$ content and subsequent annealing temperature, the PCR protocol for these primers was $94^{\circ} \mathrm{C}$ for $2 \mathrm{~min}, 40$ cycles of $94^{\circ} \mathrm{C}$ for $45 \mathrm{~s}, 65^{\circ} \mathrm{C}$ for $30 \mathrm{~s}$ (primer LHR1 $\mathrm{F}$ annealing), followed by $50^{\circ} \mathrm{C}$ for $30 \mathrm{~s}$ (primer LHR2 R annealing), and $72^{\circ} \mathrm{C}$ for $1 \mathrm{~min}$. For all other primers, PCR was performed using the touchdown protocol (Korbie and Mattick, 2008): $94^{\circ} \mathrm{C}$ for $2 \mathrm{~min} ; 10$ cycles at $94^{\circ} \mathrm{C}$ for $45 \mathrm{~s}, 10^{\circ} \mathrm{C}$ above the primer specific annealing temperature (decreasing $1^{\circ} \mathrm{C}$ in each cycle) for $30 \mathrm{~s}$, and $72^{\circ} \mathrm{C}$ for $1 \mathrm{~min}$; 30 cycles of $94^{\circ} \mathrm{C}$ for $45 \mathrm{~s}$; the primer specific annealing temperature for $30 \mathrm{~s}$; and $72^{\circ} \mathrm{C}$ for 1 min. This protocol was used to increase the reaction specificity.

\section{PCR protocol 3:}

The LHR DNA primer was used to determine whether the divergence in fragment size at the beginning of the mRNA was due to DNA deletion or alternative mRNA splicing. This PCR contained PCR buffer (1X), $\mathrm{MgCl}_{2}(2 \mathrm{mM})$, dNTPs $(0.2 \mathrm{mM})$, primers (forward and reverse, Table 1), Taq Polymerase (1 U, Promega), DNA (50 ng), DMSO (10\%), and water to a final volume of $20 \mu \mathrm{L}$. The PCR conditions for this primer were: $94^{\circ} \mathrm{C}$ for $2 \mathrm{~min}, 40$ cycles of $94^{\circ} \mathrm{C}$ for $45 \mathrm{~s}, 60^{\circ} \mathrm{C}$ for $30 \mathrm{~s}$, and $72^{\circ} \mathrm{C}$ for $1 \mathrm{~min}$. After PCR, the fragments were submitted to $1 \%$ agarose gel electrophoresis and the bands were sliced and purified using the GFX PCR DNA and Gel Band Purification Kit (GE Healthcare, Little Chalfont, UK) according to the manufacturer specifications. The concentration was quantified for each sample, which was then maintained at $-20^{\circ} \mathrm{C}$ until sequencing.

\section{DNA sequencing}

Sequencing reactions were performed using the DYEnamic ET Dye Terminator Cycle Sequencing Kit for MegaBACE DNA Analysis Systems (GE Healthcare) according to the manufacturer specifications. The products of the sequencing reactions were injected into the MegaBACE 1000 using pre-defined run parameters. The resulting chromatograms were 
evaluated using the DNA Baser software (DNA Baser Sequence Assembler v3.5.4, Heracle BioSoft SRL, www.DnaBaser.com). Sequences were aligned using the MEGA5 software (Tamura et al., 2011).

\section{Data analysis}

Information about polymorphisms (allele frequency, HWE, and fixation index) was analyzed using POPGENE (Francis et al., 1997). PIC values were determined as $2 p q$, with $p$ and $q$ being the allele frequencies of an SNP according to Botstein et al. (1980) and Petkov et al. (2004), and owing to its biallelic nature, the PIC values ranged from 0 to 0.5. Polymorphisms were tested for HWE using the G-square Likelihood ratio test at a $\mathrm{P}>0.05$ level.

\section{RESULTS}

From the sequence analyses, 21 SNPs were identified in the LH receptor mRNA. Information about the SNPs is summarized in Table 2 and their positions are demonstrated in Figure 1. For Gir cattle, the 17 SNPs identified were distributed as follows: 13 SNPs were heterozygous (SNPs 2, 3, 4, 5, 6, 7, 9, 12, 13, 16, 18, 20, and 21), which means that they were simultaneously present in two forms (e.g., A and T), and four SNPs were homozygous (SNPs $1,10,11$, and 19) and therefore, represented by one base (G, G, G, and A, respectively). For Holstein cattle, 14 SNPs were found: three were heterozygous (SNPs 3, 4, and 13) and 11 were homozygous (SNPs 1, 2, 6, 8, 10, 11, 12, 14, 15, 17, and 18, represented by G, T, C, A, $\mathrm{G}, \mathrm{G}, \mathrm{A}, \mathrm{A}, \mathrm{T}, \mathrm{T}$, and A, respectively). The sequences were compared with the cattle $L H C G R$ transcript (B. primigenius taurus) and the LHCGR sequence from GenBank (accession No. NM_174381). This analysis revealed that seven $L H C G R$ SNPs were found exclusively in Gir, while four SNPs were found only in Holstein (Table 2).

To investigate the possible physiological consequences of each SNP, their impact on amino acid translation was evaluated. Of the 21 polymorphisms identified, seven did not change the amino acid translated. Of the 14 remaining SNPs, eight produced changes between amino acids of different chemical groups.

According to the PIC values, 12 of the SNPs were classified as highly informative (PIC $>0.25)$ and three were considered to be reasonably informative $(0.25>\mathrm{PIC}>0.1)$ in Gir. In the Holstein breed, only five SNPs were considered highly informative and seven were reasonably informative. In total, eight SNPs deviated from HWE in the Gir and 11 in the Holstein breed (Table 2). Isoform evaluation revealed two alternative splice forms (Figure 2), which were both observed in agarose gels and later confirmed by sequence analysis. In one isoform, splicing in exon 1 resulted in the exclusion of 30 nucleotides beginning at position 118, but this did not lead to a change in the reading frame. The second isoform resulted from splicing at exon 10. To determine whether the loss of 30 nucleotides was the result of a DNA deletion or alternative splicing of mRNA, we performed PCR using a primer set that included a region of the mRNA (LHR1 F - exon 1) and a region of the DNA (LHR DNA R - intron 1). The results of this experiment (Figure 3) revealed that the PCR fragment was the same size $(172 \mathrm{bp})$ in samples that did and did not have the size divergence detected by sequence analysis, suggesting that the loss of 30 nucleotides was due to alternative splicing. 
Table 2. Position, allele frequencies, and statistics for polymorphisms identified in the Bovine LHCGR transcript. The highest values found are in bold.

\begin{tabular}{|c|c|c|c|c|c|c|c|c|c|}
\hline Breed & SNPs & Position $^{\mathrm{a}}$ & Exon & $\begin{array}{l}\text { Nucleotide change } \\
\text { (Normal-Variant) }\end{array}$ & $\begin{array}{l}\text { Amino acid change } \\
\text { (Normal } \rightarrow \text { Variant) }\end{array}$ & $\begin{array}{l}\text { Normal allele } \\
\text { frequency }\end{array}$ & $\begin{array}{l}\text { Variant allele } \\
\text { frequency }\end{array}$ & $\mathrm{PIC}^{\mathrm{b}}$ & $\operatorname{HWE}^{\mathrm{c}}(\mathrm{P})$ \\
\hline \multirow[t]{17}{*}{ Gir } & SNP1 & 28 & 1 & C-G & Leu $\rightarrow$ Val & 0.11 & 0.89 & 0.20 & $<0.01$ \\
\hline & SNP2 & 53 & 1 & C-T & Pro $\rightarrow$ Leu & 0.21 & 0.79 & 0.33 & $>0.05$ \\
\hline & SNP3 & 413 & 5 & A-G & His $\rightarrow$ Arg & 0.57 & 0.43 & 0.49 & $>0.05$ \\
\hline & SNP4 & 496 & 6 & A-G & $\mathrm{Ile} \rightarrow \mathrm{Val}^{*}$ & 0.57 & 0.43 & 0.49 & $>0.05$ \\
\hline & SNP5 & 539 & 6 & C-T & Thr $\rightarrow$ Met* & 0.63 & 0.37 & 0.47 & $>0.05$ \\
\hline & SNP6 & 703 & 9 & A-C & Lys $\rightarrow \mathrm{Gln}^{*}$ & 0.83 & 0.17 & 0.28 & $>0.05$ \\
\hline & SNP7 & 726 & 9 & C-T & Tyr & 0.87 & 0.13 & 0.23 & $>0.05$ \\
\hline & SNP9 & 870 & 9 & C-T & Asn & 0.77 & 0.23 & 0.35 & $<0.01$ \\
\hline & SNP10 & 876 & 10 & A-G & Gln & 0.20 & 0.80 & 0.32 & $<0.001$ \\
\hline & SNP11 & 1084 & 11 & A-G & Asn $\rightarrow$ Asp* & 0.27 & 0.73 & 0.39 & $<0.001$ \\
\hline & SNP12 & 1131 & 11 & G-A & Thr & 0.23 & 0.77 & 0.35 & $<0.01$ \\
\hline & SNP13 & 1210 & 11 & T-G & Ser $\rightarrow$ Ala* & 0.77 & 0.23 & 0.35 & $>0.05$ \\
\hline & SNP16 & 1328 & 11 & C-T & Ala $\rightarrow$ Val & 0.23 & 0.77 & 0.35 & $<0.001$ \\
\hline & SNP18 & 1501 & 11 & G-A & $\mathrm{Val} \rightarrow \mathrm{Met}$ & 0.37 & 0.63 & 0.47 & $<0.001$ \\
\hline & SNP19 & 1666 & 11 & C-A & Gln $\rightarrow$ Lys* & 0.87 & 0.13 & 0.23 & $<0.001$ \\
\hline & SNP20 & 1770 & 11 & T-C & Phe & 0.97 & 0.03 & 0.06 & $>0.05$ \\
\hline & SNP21 & 1916 & 11 & T-G & Leu $\rightarrow$ Trp* & 0.97 & 0.03 & 0.06 & $>0.05$ \\
\hline \multirow[t]{14}{*}{ Holstein } & SNP1 & 28 & 1 & C-G & Leu $\rightarrow$ Val & 0.00 & 1.00 & 0 & \\
\hline & SNP2 & 53 & 1 & C-T & Pro $\rightarrow$ Leu & 0.80 & 0.20 & 0.32 & $<0.05$ \\
\hline & SNP3 & 413 & 5 & A-G & His $\rightarrow$ Arg & 0.93 & 0.07 & 0.13 & $>0.05$ \\
\hline & SNP4 & 496 & 6 & A-G & $\mathrm{Ile} \rightarrow \mathrm{Val}^{*}$ & 0.97 & 0.03 & 0.06 & $>0.05$ \\
\hline & SNP6 & 703 & 9 & A-C & Lys $\rightarrow$ Gln* & 0.79 & 0.21 & 0.33 & $<0.001$ \\
\hline & SNP8 & 771 & 9 & T-A & Ser & 0.92 & 0.08 & 0.15 & $<0.01$ \\
\hline & SNP10 & 876 & 10 & A-G & Gln & 0.42 & 0.58 & 0.49 & $<0.001$ \\
\hline & SNP11 & 1084 & 11 & A-G & Asn $\rightarrow$ Asp* & 0.93 & 0.07 & 0.13 & $<0.01$ \\
\hline & SNP12 & 1131 & 11 & G-A & Thr & 0.93 & 0.07 & 0.13 & $<0.01$ \\
\hline & SNP13 & 1210 & 11 & T-G & Ser $\rightarrow$ Ala* & 0.60 & 0.40 & 0.48 & $<0.01$ \\
\hline & SNP14 & 1224 & 11 & C-A & Phe $\rightarrow$ Leu* & 0.93 & 0.07 & 0.13 & $<0.01$ \\
\hline & SNP15 & 1253 & 11 & C-T & Ala $\rightarrow$ Val & 0.93 & 0.07 & 0.13 & $<0.01$ \\
\hline & SNP17 & 1470 & 11 & C-T & Leu & 0.93 & 0.07 & 0.13 & $<0.01$ \\
\hline & SNP18 & 1501 & 11 & G-A & Val $\rightarrow$ Met & 0.67 & 0.33 & 0.44 & $<0.001$ \\
\hline
\end{tabular}

${ }^{\text {aStarting }}$ at the first ATG in the GenBank sequence (accession No. NM_174381); *Amino acid group change; ${ }^{\text {bPIC }}$

$=$ Polymorphic information content; ${ }^{c} \mathrm{HWE}=$ Hardy-Weinberg equilibrium.

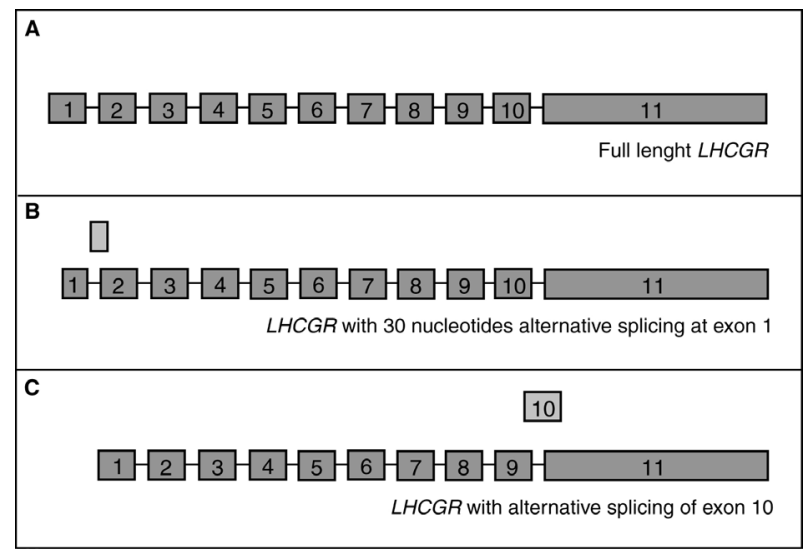

Figure 2. Alternative splicing of the luteinizing hormone/choriogonadotropin receptor $(L H C G R)$ mRNA. A. Full length receptor containing 11 exons; B. LH receptor showing an alternative splicing of 30 nucleotides at exon 1; C. $\mathrm{LG}$ receptor showing an alternative splicing of entire exon 10. 


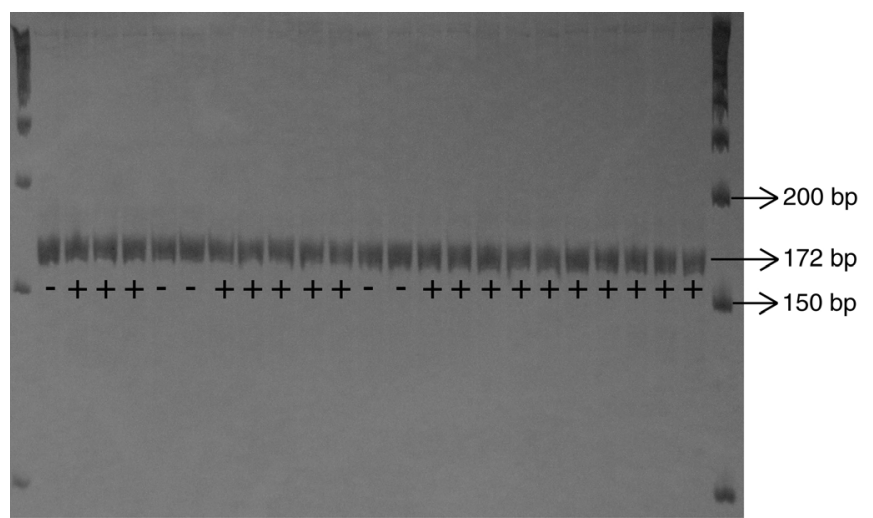

Figure 3. Electrophoresis (acrylamide gel, 5\%) of PCR products to investigate the possible DNA deletion. +, samples presenting the absence of 30 nucleotides in the mRNA sequenced fragments; -, samples with the full mRNA sequenced fragment; bp, base pair. The ladder used identifies molecular weights at 50-bp intervals.

\section{DISCUSSION}

The aim of this study was to identify SNPs and alternative spliced isoforms of $L H C G R$ transcripts in dairy cattle breeds. The novelty of this study was that we compared the different SNPs present in B. primigenius indicus (Gir) and in B. primigenius taurus (Holstein) LHCGR. In addition, we describe, for the first time, alternative splicing of exon 1.

To infer the physiological consequences of SNPs in the function of LHCGR, we analyzed the impact of polymorphisms on translation. Of the 21 polymorphisms identified, seven did not change the amino acid translated. Eight of the remaining SNPs resulted in the translation of amino acids belonging to different chemical groups. Therefore, SNPs could cause changes in the tertiary structure of the translated protein and eventually alter functional properties, such as the binding affinity of LHCGR. However, the three-dimensional structure of the LHCGR binding site, even in humans, has not been determined (Puett et al., 2010). As a result, the physiological relevance of SNPs identified in this study remains to be elucidated. Even SNPs that do not cause a change in amino acids can cause preferential codon translation (Novoa and Ribas de Pouplana, 2012), which may be related to different reproductive phenotypes.

SNP16, found exclusively in Gir samples, has been previously described in the Nelore, a B. primigenius indicus beef breed (Santos-Biase et al., 2012), suggesting that this SNP is a variant specific to Zebu cattle. The authors suggested that this polymorphism affects the number of viable oocytes produced for in vitro fertilization procedures. Consistently, the Gir breed has a higher average follicular population during the estrous cycle and produces more cumulus-oocyte complexes (COC) after ultrasound-guided follicular aspiration than the Holstein breed (Pontes et al., 2010). Interestingly, SNP16 was found in heterozygosis, and there is great variation in follicular population and COC yield among Gir donors (Viana et al., 2010), suggesting that SNP16 may be an interesting target for further reproductive phenomic studies.

In our study, SNP17 was found exclusively in Holstein samples. This SNP has been previously identified in another study using $B$. primigenius taurus cattle, in the British Friesian and North American Holstein breeds (Hastings et al., 2006). Like SNP16 in Zebu cattle, SNP17 may be specific to European breeds. However, this polymorphism did not result in an amino acid change and is, therefore, unlikely to modify protein folding. Hastings et al. (2006) 
identified two additional SNPs (positions $1401 \mathrm{G}^{\circledR} \mathrm{T}$ and $1581 \mathrm{G}^{\circledR} \mathrm{T}$ ), which were not detected in the Gir or Holstein samples used in our study.

Due to its importance for the regulation of ovarian function, it might be expected that the LHCGR sequence would be highly conserved among animals. However, even in critical genes, some variability is important for phenotypic plasticity and natural selection (MignonGrasteau et al., 2005). Artificial selection pressure for production traits might alter this balance and could lead to increased inbreeding and changes in the genetic variation of other traits. The number of polymorphisms found in our study may reflect differences caused by selection pressures for many traits applied differently to the two subspecies evaluated. The Gir breed, which has been intensively selected only recently, presented the highest genetic variability, with only four homozygous SNPs out of the 17 identified, while in the Holstein breed, which has been intensively selected for decades, 11 out of 14 SNPs were homozygous.

The results of PIC and HWE analyses (Table 2) support previous findings and suggest that the frequency of $L H C G R$ alleles is changing, and this may have been driven by strong selection pressure for milk production in dairy cattle breeds or by the mating systems imposed to the populations under selection, e.g., inbreeding. Directional selection increases the rate of inbreeding compared with random selection because it increases the probability for co-selection of relatives when compared with random selection within and over generations (Kristensen and Sorensen, 2005). The relatively small number of sires intensively used in Brazilian dairy Gir cattle, the rapid dissemination of this breed, and the selection focused on milk production have contributed to increase the inbreeding coefficient, which may result in reproductive, productive, and economic losses (Santana Jr et al., 2014). In the last decade, there has been a significant increase in the use of in vitro embryo production techniques in this breed (Viana et al., 2012), particularly with sex-sorted semen. This leads to the selection of fewer parents, a higher variance of reproductive success (and family size) and, therefore, an increased rate of inbreeding (Kristensen and Sorensen, 2005). In Holstein cattle, the negative effect of selection for milk production on reproductive performance is well known. However, whether this is a direct effect or one mediated by altered metabolic parameters in high producing cows remains controversial (Butler, 2013).

This study also led to the identification of two alternative splice variants (Figure 2), one in exon 1, and the other in exon 10. These data provide the first description of splicing at exon 1. Previous studies may have missed exon 1 splicing because the high CG content in this region required methodological adaptations for appropriate screening. The increased GC content (\%) in the DNA affects amplification efficiency, because GC-rich primers and DNA templates can hamper denaturation, annealing, and extension in the course of PCR amplifications (McDowell et al., 1998, Li et al., 2011). A PCR amplification cycle is comprised of three steps: DNA melting, primer annealing, and extension. The primary cause of ineffective PCR amplification is low efficiency of primer annealing. Therefore, primer properties are of vital importance for PCR amplification, especially for those used to amplify GC-rich DNA templates. Most literature affirms that primer design should minimize the formation of secondary structures. However, there is less information on how to adjust the other parameters of primer design ( $\mathrm{Li}$ et al., 2011). It is usually suggested that the forward and reverse primer annealing temperatures should be as similar as possible. However, this is not always possible because the regions that primers are designed for do not present the same GC content in every situation. To successfully amplify the initial region of the LHCGR mRNA, we used primers (forward and reverse) with different annealing temperatures (approximately 
$15^{\circ} \mathrm{C}$ ), which required a two-stage annealing step in the PCR. Exon 1 splicing caused a loss of $30 \mathrm{bp}$, but did not change the reading frame. Further studies are necessary to elucidate the importance of these isoforms.

The second splicing variant found was missing of the whole sequence of exon 10 . This variant has been previously described in cattle (Robert et al., 2003; Nogueira et al., 2007) and in humans (Müller et al., 2003; Madhra et al., 2004). This isoform is reportedly more responsive to human chorionic gonadotropin (hCG) than to LH (Müller et al., 2003), although its biological relevance remains unclear. Full-length $L H C G R$ and both isoforms were detected in all samples, suggesting that the expression of different forms of $L H C G R$ plays a role in GC function.

In conclusion, $L H C G R$ shows a high frequency of polymorphisms and multiple isoforms generated by alternative splicing despite its role in a highly conserved mechanism. Together, these results provide genomic and transcriptomic information that may be used in further association studies to evaluate how $L H C G R$ variants are related to reproductive phenotypes.

\section{Conflicts of interest}

The authors declare no conflict of interest.

\section{ACKNOWLEDGMENTS}

The authors would like to thank CNPq Project \#477701/2011-6 and Fapemig CVZ PPM \#0067/11 for financial support and Fapemig for the DSc scholarship to S. WohlresViana. The authors also thank Fazendas do Basa for allowing us to sample animals from their herd and Elsevier's language editing service for reviewing the manuscript.

\section{REFERENCES}

Abdennebi L, Lesport AS, Remy JJ, Grebert D, et al. (2002). Differences in splicing of mRNA encoding LH receptor in theca cells according to breeding season in ewes. Reproduction 123: 819-826. http://dx.doi.org/10.1530/ rep. 0.1230819

Adams GP, Jaiswal R, Singh J and Malhi P (2008). Progress in understanding ovarian follicular dynamics in cattle. Theriogenology 69: 72-80. http://dx.doi.org/10.1016/j.theriogenology.2007.09.026

Arashiro EKN, Palhao MP, Santos JRL, Fontes RC, et al. (2013a). Three-dimensional modeling of color Doppler images: a new approach to study follicular vascularization in cattle. Anim. Reprod. 10: 662-669.

Arashiro EKN, Palhao MP, Wohlres-Viana S, Siqueira LGB, et al. (2013b). In vivo collection of follicular fluid and granulosa cells from individual follicles of different diameters in cattle by an adapted ovum pick-up system. Reprod. Biol. Endocrinol. 11: 73-80. http://dx.doi.org/10.1186/1477-7827-11-73

Botstein D, White RL, Skolnick M and Davis RW (1980). Construction of a genetic linkage map in man using restriction fragment length polymorphisms. Am. J. Hum. Genet. 32: 314-331.

Butler ST (2013). Genetic control of reproduction in dairy cows. Reprod. Fertil. Dev. 26: 1-11. http://dx.doi.org/10.1071/ RD13304

Espey LL and Lipner H (2006). Ovulation. In: The physiology of reproduction, 3rd ed. (Knobil E and Neill JD, eds.). Elsevier, The Netherlands, pp. 425-474.

Francis Y, Yang RC, Boyle RC, Timothy BJ, et al. (1997). POPGENE, the user-friendly shareware for population genetic analysis. Molecular Biology and Biotechnology Centre, University of Alberta, Edmonton.

Ginther OJ, Beg MA, Bergfelt DR, Donadeu FX, et al. (2001a). Follicle selection in monovular species. Biol. Reprod. 65: 638-647. http://dx.doi.org/10.1095/biolreprod65.3.638

Ginther OJ, Bergfelt DR, Beg MA and Kot K (2001b). Follicle selection in cattle: role of luteinizing hormone. Biol. Reprod. 64: 197-205. http://dx.doi.org/10.1095/biolreprod64.1.197 
Hastings N, Donn S, Derecka K, Flint AP, et al. (2006). Polymorphisms within the coding region of the bovine luteinizing hormone receptor gene and their association with fertility traits. Anim. Genet. 37: 583-585. http://dx.doi.org/10.1111/ j.1365-2052.2006.01532.x

Kawate N (2004). Studies on the regulation of expression of luteinizing hormone receptor in the ovary and the mechanism of follicular cyst formation in ruminants. J. Reprod. Dev. 50: 1-8. http://dx.doi.org/10.1262/jrd.50.1

Korbie DJ and Mattick JS (2008). Touchdown PCR for increased specificity and sensitivity in PCR amplification. Nat. Protoc. 3: 1452-1456. http://dx.doi.org/10.1038/nprot.2008.133

Kristensen TN and Sorensen AC (2005). Inbreeding - lessons from animal breeding, evolutionary biology and conservation genetics. Anim. Sci. 80: 121-133. http://dx.doi.org/10.1079/ASC41960121

Li LY, Li Q, Yu YH, Zhong M, et al. (2011). A primer design strategy for PCR amplification of GC-rich DNA sequences. Clin. Biochem. 44: 692-698.http://dx.doi.org/10.1016/j.clinbiochem.2011.02.001

McDowell DG, Burns NA and Parkes HC (1998). Localised sequence regions possessing high melting temperatures prevent the amplification of a DNA mimic in competitive PCR. Nucleic Acids Res. 26: 3340-3347. http://dx.doi. org $/ 10.1093 /$ nar/26.14.3340

Madhra M, Gay E, Fraser HM and Duncan WC (2004). Alternative splicing of the human luteal LH receptor during luteolysis and maternal recognition of pregnancy. Mol. Hum. Reprod. 10: 599-603.http://dx.doi.org/10.1093/molehr/ gah076

Marson EP, Ferraz JBS, Meirelles FV, Balieiro JCC, et al. (2008). Effects of polymorphisms of LHR and FSHR genes on sexual precocity in a Bos taurus x Bos indicus beef composite population. Genet. Mol. Res. 7: 243-251. http://dx.doi. org/10.4238/vol7-1 gmr418

Mignon-Grasteau S, Boissy A, Bouix J, Faure JM, et al. (2005). Genetics of adaptation and domestication in livestock. Livest. Prod. Sci. 93: 3-14. http://dx.doi.org/10.1016/j.livprodsci.2004.11.001

Müller T, Gromoll J and Simoni M (2003). Absence of exon 10 of the human luteinizing hormone (LH) receptor impairs LH, but not human chorionic gonadotropin action. J. Clin. Endocrinol. Metab. 88: 2242-2249. http://dx.doi. org/10.1210/jc.2002-021946

Nogueira MFG, Buratini J, Jr., Price CA, Castilho ACS, et al. (2007). Expression of LH receptor mRNA splice variants in bovine granulosa cells: changes with follicle size and regulation by FSH in vitro. Mol. Reprod. Dev. 74: 680-686. http://dx.doi.org/10.1002/mrd.20656

Novoa EM and Ribas de Pouplana L (2012). Speeding with control: codon usage, tRNAs, and ribosomes. Trends Genet. 28: 574-581.http://dx.doi.org/10.1016/j.tig.2012.07.006

Petkov PM, Ding Y, Cassell MA, Zhang W, et al. (2004). An efficient SNP system for mouse genome scanning and elucidating strain relationships. Genome Res. 14: 1806-1811.http://dx.doi.org/10.1101/gr.2825804

Pontes JH, Silva KC, Basso AC, Rigo AG, et al. (2010). Large-scale in vitro embryo production and pregnancy rates from Bos taurus, Bos indicus, and indicus-taurus dairy cows using sexed sperm. Theriogenology 74: 1349-1355. http:// dx.doi.org/10.1016/j.theriogenology.2010.06.004

Puett D, Angelova K, da Costa MR, Warrenfeltz SW, et al. (2010). The luteinizing hormone receptor: insights into structure-function relationships and hormone-receptor-mediated changes in gene expression in ovarian cancer cells. Mol. Cell. Endocrinol. 329: 47-55.http://dx.doi.org/10.1016/j.mce.2010.04.025

Robert C, Gagné D, Lussier JG, Bousquet D, et al. (2003). Presence of LH receptor mRNA in granulosa cells as a potential marker of oocyte developmental competence and characterization of the bovine splicing isoforms. Reproduction 125: 437-446. http://dx.doi.org/10.1530/rep.0.1250437

Royal MD, Darwash AO, Flint APF, Webb R, et al. (2000). Declining fertility in dairy cattle: changes in traditional and endocrine parameters of fertility. Anim. Sci. 70: 487-501.

Santana Jr ML, Pereira RJ, Bignardi AB, El Faro L, et al. (2014). History, structure, and genetic diversity of Brazilian Gir cattle. Livest. Sci. 163: 26-33. http://dx.doi.org/10.1016/j.livsci.2014.02.007

Santos-Biase WK, Biase FH, Buratini J, Jr., Balieiro J, et al. (2012). Single nucleotide polymorphisms in the bovine genome are associated with the number of oocytes collected during ovum pick up. Anim. Reprod. Sci. 134: 141-149. http://dx.doi.org/10.1016/j.anireprosci.2012.08.017

Sartori R, Bastos MR, Baruselli PS, Gimenes LU, et al. (2010). Physiological differences and implications to reproductive management of Bos taurus and Bos indicus cattle in a tropical environment. Soc. Reprod. Fertil. Suppl. 67: 357-375.

Tamura K, Peterson D, Peterson N, Stecher G, et al. (2011). MEGA5: molecular evolutionary genetics analysis using maximum likelihood, evolutionary distance, and maximum parsimony methods. Mol. Biol. Evol. 28: 2731-2739. http://dx.doi.org/10.1093/molbev/msr121

Themmen APN (2005). An update of the pathophysiology of human gonadotrophin subunit and receptor gene mutations and polymorphisms. Reproduction 130: 263-274.http://dx.doi.org/10.1530/rep.1.00663 
Viana JH, Palhao MP, Siqueira LG, Fonseca JF, et al. (2010). Ovarian follicular dynamics, follicle deviation, and oocyte yield in Gyr breed (Bos indicus) cows undergoing repeated ovum pick-up. Theriogenology 73: 966-972. http://dx.doi. org/10.1016/j.theriogenology.2009.11.025

Viana JH, Siqueira LG, Palhao MP and Camargo LS (2012). Features and perspectives of the Brazilian in vitro embryo industry. Anim. Reprod. 9: 12-18.

Washburn SP, Silvia WJ, Brown CH, McDaniel BT, et al. (2002). Trends in reproductive performance in Southeastern Holstein and Jersey DHI herds. J. Dairy Sci. 85: 244-251. http://dx.doi.org/10.3168/jds.S0022-0302(02)74073-3

Weigel K (2004). Improving the reproductive efficiency of dairy cattle through genetic selection. J. Dairy Sci. 87: E86-E92. http://dx.doi.org/10.3168/jds.S0022-0302(04)70064-8 